The University of Maine

\title{
DigitalCommons@UMaine
}

Marine Sciences Faculty Scholarship

School of Marine Sciences

$10-1-2007$

\section{Anthropogenic Impacts on the Corner Rise Seamounts, North-West Atlantic Ocean}

\author{
Rhian Waller \\ University of Maine - Main, rhian.waller@maine.edu \\ Les Watling \\ University of Maine - Main, watling@maine.edu \\ P. Auster
}

T. Shank

Follow this and additional works at: https://digitalcommons.library.umaine.edu/sms_facpub

\section{Repository Citation}

Waller, Rhian; Watling, Les; Auster, P.; and Shank, T., "Anthropogenic Impacts on the Corner Rise Seamounts, North-West Atlantic Ocean" (2007). Marine Sciences Faculty Scholarship. 15.

https://digitalcommons.library.umaine.edu/sms_facpub/15 


\title{
Anthropogenic impacts on the Corner Rise seamounts, north-west Atlantic Ocean
}

\author{
Rhian Waller*§, Les Watling ${ }^{\dagger+}$, Peter Auster` and Timothy Shank* \\ *Biology Department, Woods Hole Oceanographic Institution, Woods Hole, MA 02543, USA. †Darling Marine Center, University \\ of Maine, Walpole, ME 04573, USA. `Department of Zoology, University of Hawaii at Manoa, Honolulu, HI 96822, USA. `National \\ Undersea Research Center, University of Connecticut, Groton, CT 06340, USA. \$Corresponding author, e-mail: rwaller@whoi.edu
}

Here we report the first direct underwater observations of extensive human-caused impacts on two remote seamounts in the Corner Rise complex (north-western Atlantic). This note documents evidence of anthropogenic damage on the summits of Kükenthal peak (on Corner Seamount) and Yakutat Seamount, likely resulting from a limited Russian fishery from the mid-1970s to the mid-1990s, highlighting how bottom trawling can have long-term detrimental effects on deepwater benthic fauna.

Seamount and ridge fisheries in the North Atlantic have targeted such species groups as grenadiers (Macrouridae), alfonsinos (Berycidae), smoothheads (Alepocephalidae), codlings (Moridae), oreos (Oreosomatidae), cutlassfish (Trichiuridae) and roughies (Trachichthyidae) (e.g. Vinnichenko, 1997; ICES, 2006). Many nations participate in these fisheries with the obligation to report catches of managed species to the Regional Fishery Management Organizations (RFMO). However, there are no obligations to report bycatch associated with these fisheries as a way of understanding the broader environmental impacts, yet it is widely recognized that seamounts are often areas of high benthic biodiversity, with many deep-water coral ecosystems prevalent. The removal of longlived corals and other large and sensitive biogenic structures as a consequence of deep-sea fisheries is well documented throughout the world's oceans (see references in Corcoran \& Hain, 2006) and is the rationale for developing strong high-seas conservation measures throughout the globe (UNEP, 2006).

The Corner Rise seamounts (Figure 1) lie west of the Mid-Atlantic Ridge, approximately $2000 \mathrm{~km}$ from land (both the Azores and the US coast). This seamount cluster consists of around 20 seamounts emerging out of $6000 \mathrm{~m}$ water depth, with the shallowest peak rising to $700 \mathrm{~m}$. For twenty years (1976-1996) the Union of Soviet Socialist Republics (USSR) (now the Russian Federation) expended significant effort in the area of the Corner Rise seamounts using both pelagic and bottom trawls (Vinnichenko, 1997). These seamounts lie within the North-west Atlantic Fisheries Organization (NAFO) RFMO to which the USSR has been a signatory since it was established in 1979. Though many fish species were recorded in this fishery, there is no information on invertebrate bycatch. As part of a broader study on deep-water corals of the North Atlantic, we investigated 5 seamounts in the Corner Rise complex using a remotely operated vehicle (ROV) in August 2005 and documented not only pristine coral ecosystems (Figure 2A), but also dramatic evidence of large-scale trawling damage on the summits of Kükenthal peak $\left(35^{\circ} 31.645^{\prime} \mathrm{N} 51^{\circ} 55.467^{\prime} \mathrm{W}, 730 \mathrm{~m}\right)$ and Yakutat Seamount $\left(35^{\circ} 16.831^{\prime} \mathrm{N} 48^{\circ} 05.557^{\prime} \mathrm{W}, 1425 \mathrm{~m}\right)$ likely resulting from this Russian fishery (Vinnichenko, 1997).

Our observations on the top plateau of Yakutat Seamount revealed multiple scars, resultant scleractinian (Lophelia pertusa) debris, broken soft coral branches (Paragorgia sp.) and broken manganese crusts (Figure 2B\&C) from the ground gear of trawls. Paragorgia branches were also scattered in abundance on the slope leading to the top plateau, possibly having been broken and cast down-slope, or transported after breakage. The number of live corals documented on the plateau was negligible compared to other seamounts we visited during the expedition (10 in total). The

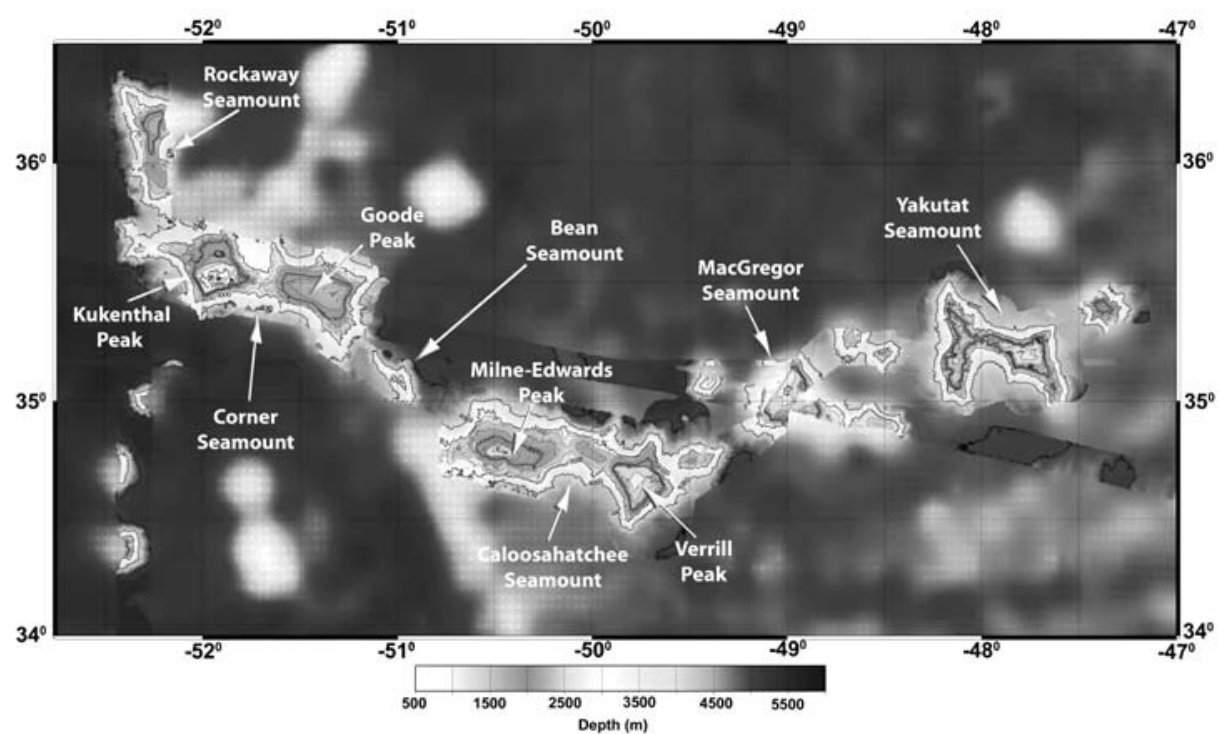

Figure 1. Multibeam bathymetric map generated during a cruise on the Corner Rise seamount complex, north-western Atlantic Ocean. Both individual seamounts and the highest peaks within those seamounts are labelled. 


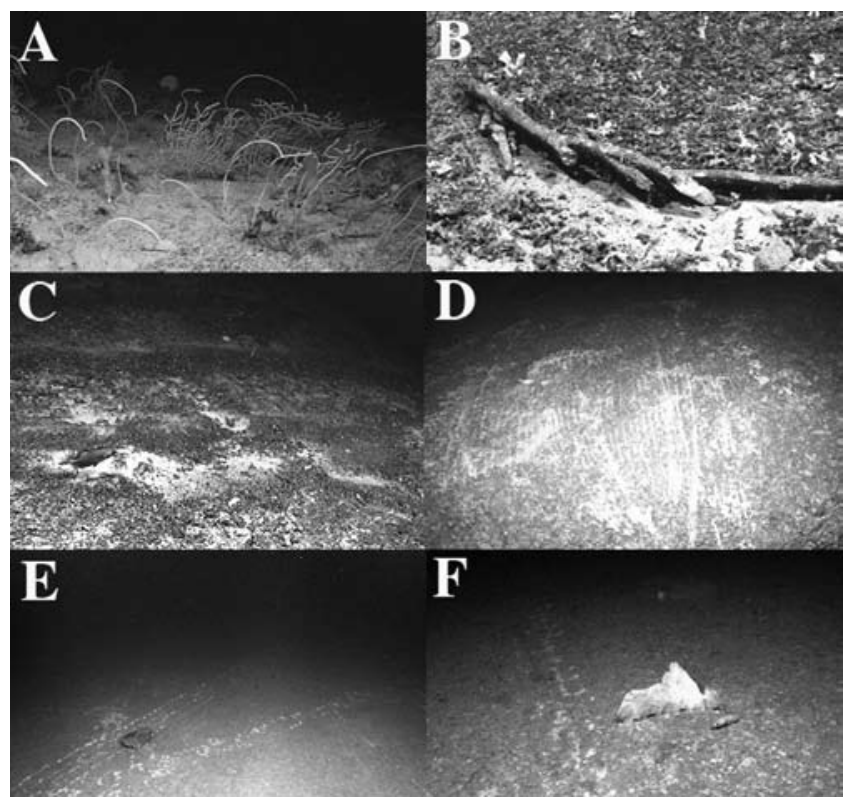

Figure 2. High definition video frame grabs from the Corner Rise seamounts. (A) Corner Seamount (1220 m), area showing a soft coral community of Paramuricea sp., Calyptrophora sp. and Chrysogorgia sp.; (B) Yakutat Seamount (1500 m), broken octocoral branch, possibly Paragorgia sp.; (C) Yakutat Seamount (1430 m), linear scar lines across the top of the seamount, Neocyttus helgae in left foreground; (D) Kükenthal peak on Corner Seamount $(800 \mathrm{~m})$, large scar marks on the edge of the summit caused by gear impacts; (E) Kükenthal peak on Corner Seamount (725 m), gear marks and a displaced boulder; and (F) Kükenthal peak on Corner Seamount $(750 \mathrm{~m})$, an 'amphitheatre sponge' being used by a Laemonema sp. fish as physical habitat. Trawl scar to the left of the sponge.

oreosomatid, Neocyttus helgae, was the only fish species of current economic importance observed (Figure 2G), but was present in exceptionally low numbers.

Our investigation of Kükenthal peak started with a traverse up a large cemented carbonate wall. On reaching the top, large scar marks were particularly evident on the edges, following onto the main plateau (Figure 2D). The deeper edges of the plateau hosted sparse Parantipathes sp. (black coral) in a veneer of sediment. Summit communities were dominated by white hexactinellid 'amphitheatre' sponges, some with associated fish (Laemonema sp. (Figure 2F), Physiculus fulvus and Hoplostethus mediterraneus). At $\sim 730$ $\mathrm{m}$ the sponge zone ceased and sessile fauna were conspicuously absent. Numerous multi-directional trawl scars $(\sim 20 \mathrm{~cm}$ width, $\sim 10$ individual tracks per $5 \mathrm{~m}^{2}$ maximum-Figure 2D\&E), displaced boulders (Figure 2E) and metallic waste were all observed in high numbers. Small colonies of live L. pertusa were observed at plateau edges with dead fragments on the summit, suggesting this species was previously common.

The creation of areas closed to destructive fishing practices have been enacted in many locations. A number of Marine Protected Areas (MPAs) have been proposed in the North Atlantic, specifically to protect deep-water coral habitats (e.g. The Darwin Mounds in the Rockall Trough, Thérèse Mound in the Porcupine Seabight and the Sula Reef off the Norwegian continental shelf), as well as in other parts of the world's oceans (Corcoran \& Hain, 2006). Though many countries have banned bottom trawling within parts of their Exclusive Economic Zones (EEZs), to date there are few areas beyond national jurisdiction (High Seas) that are protected, thus the majority of areas where deep-water corals and their associated high biodiversity are found are under threat (Corcoran \& Hain, 2006). Though a moratorium on deep-water trawling was proposed to the United Nations General Assembly in November 2006, no consensus was reached. However, while nations must now consider the impact of deep-water fishing activities on vulnerable marine ecosystems in international waters, and 'close such areas to bottom fishing and ensure that such activities do not proceed unless conservation and management measures have been established to prevent significant adverse impacts ...' such actions will require a country by country approach (United Nations, Agenda of the 61st session of the General Assembly, 7 December 2006, A/60/251). The absence of strong international action on this issue therefore leaves coral communities vulnerable to anthropogenic damage.

Prior to these observations the effects of deep-water trawling on North Atlantic seamounts have been unknown (Morato \& Pauly, 2004). These observations from the Corner Rise are the first visual verification of trawling damage to this remote area, and provide evidence that seamount fishing impacts were intensive and similar to those reported from Australia and New Zealand. Numerous types of scars and impacts were observed suggesting seafloor contact from various components of fishing gear (i.e. wide scars, broken crusts, displaced boulders and upturned corals presumably from trawl doors or ground gear, and narrow scars and cuts through sponges either from trawl weights or long-line components). The summits of Yakutat and Kükenthal have been effectively denuded of large sessile fauna, and no longer support habitat forming corals in any significant numbers, unlike other seamounts and peaks within the Corner Rise complex. In the absence of species' colonization and growth rates, it is impossible to accurately estimate the time required for these areas to fully recover their former biodiversity, though if fishing effort indeed ended in the mid-1990s as effort data suggests (Vinnichenko, 1997), and the habitats observed are 'in recovery', then time to full recovery may be decades to centuries. In the broader context, as continental shelf fish populations decline and fishing regulations become stricter, the continual movement of vessels into high seas fisheries makes the extent of seamount biodiversity loss difficult, if not impossible, to determine.

This work was supported by the NOAA Ocean Exploration Program (T.S. and R.W., OAR4601054; and P.A. and L.W., OAR4601061). We thank the captain, crew and fellow science party members of the Deep Atlantic Stepping Stones Expedition (NOAA Ship 'Ronald H. Brown') and in particular the pilots and technicians of the Argus-Hercules ROV system (IFE \& University of Rhode Island IAO). The views expressed herein are those of the authors and do not necessarily reflect the views of NOAA or their subagencies.

\section{REFERENCES}

Corcoran, E. \& Hain, S., 2006. Cold-water coral reefs: status and conservation. In Conservation biology 13, coral reef conservation (ed. I.M. Côté and J.D. Reynolds), pp. 115-144. Cambridge: Cambridge University Press.

ICES, 2006. Report of the Working Group on Deep-water Ecology (WGDEC), 4-7 December 2005, Miami, USA. ICES CM 2006/ ACE:04. 79 pp.

Morato, T., \& Pauly, D., 2004. Seamounts: biodiversity and fisheries. Fisheries Centre Research Report, no.12(5).

UNEP (2006). Ecosystems and biodiversity in deep waters and high seas. UNEP Regional Seas Reports and Studies. Switzerland: UNEP/IUCN: 58.

Vinnichenko, V.I., 1997. Russian investigations and deep water fishery on the Corner Rising Seamount in Subarea 6. NAFO Scientific Council Studies, 30, 41-49. 